\title{
AKTSAR
}

ISSN 2622-5255 (online)

Volume 2 Nomor 2, Juni 2019, Halaman 187-198

ISSN 2622-2345 (cetak)

\section{Pengaruh Nilai Tukar, Tingkat Pertumbuhan Ekonomi, Dan Tingkat Inflasi Terhadap Jakarta Islamic Index}

\author{
Surepno \\ Institut Agama Islam Negeri Kudus \\ surepno@iainkudus.ac.id \\ Aqinatul Munawaroh Agustina \\ Institut Agama Islam Negeri Kudus \\ Aqinatul2346@gmail.com \\ Abdul Haris Naim \\ Institut Agama Islam Negeri Kudus \\ Harisnaim869@gmail.com
}

ABSTRACT

The purpose of this study was to analyze the effect of the rupiah exchange rate, economic growth and inflation on the Jakarta Islamic Index. This type of research is quantitative research with secondary data sources. The sampling method uses purposive sampling method. The data analysis method used in this research is multiple linear regression analysis. The results of this study indicate that partially the rupiah exchange rate has a significant effect on Jakarta Islamic Index while economic growth and inflation have no significant effect on Jakarta Islamic Index. Simultaneously variables of the rupiah exchange rate, economic growth and inflation significantly influence the Jakarta Islamic Index.

Keywords: Exchange Rater; Economic Growth; Inflation; and Jakarta Islamic Index 
Tujuan penelitian ini adalah menganalisis pengaruh nilai tukar rupiah, pertumbuhan ekonomi, dan inflasi terhadap Jakarta Islamic Index. Jenis penelitian ini adalah penelitian kuantitatif dengan sumber data sekunder. Metode pengambilan sampel menggunakan metode purposive sampling. Metode analisis data yang digunakan dalam penelitian ini adalah analisis regresi linier berganda. Hasil penelitian ini menunjukkan bahwa secara parsial nilai tukar rupiah berpengaruh secara signifikan terhadap Jakarta Islamic Index sedangkan pertumbuhan ekonomi dan inflasi tidak berpengaruh secara signifikan terhadap Jakarta Islamic Index. Secara simultan variabel nilai tukar rupiah, pertumbuhan ekonomi, dan inflasi berpengaruh secara signifikan terhadap Jakarta Islamic Index.

\section{Kata kunci: Nilai Tukar; Pertumbuhan Ekonomi; Inflasi; dan Jakarta Islamic Index}

\section{PENDAHULUAN}

Instrumen perekonomian makro suatu negara pada prinsipnya ditunjukkan dua sektor, yaitu sektor keuangan dan sektor riil. Kedua sektor tersebut merupakan mata rantai yang saling terkait satu sama lain, gangguan pada salah satu sektor mempengaruhi kelangsungan dan stabilitas ekonomi. Sektor keuangan dalam perekonomian agregat berarti lalu lintas penawaran dan permintaan antar sektor keuangan. Penawaran dan permintaan sektor keuangan sering disebut pasar keuangan. Pasar keuangan adalah mekanisme dimana peminjam-peminjam bertemu dan melakukan jual beli instrumen keuangan. Dengan demikian, pasar finansial meliputi pasar uang dan pasar modal (Hadi, 2015).

Pasar modal merupakan salah satu alternatif sumber pendanaan bagi perusahaan sekaligus sebagai sarana investasi bagi para pemodal. Kegiatan- kegiatan di pasar modal dapat dikategorikan sebagai kegiatan ekonomi yang termasuk dalam kegiatan muamalah, yaitu suatu kegiatan yang mengatur hubungan perniagaan. Menurut kaidah fiqh, hukum asal dari kegiatan muamalah adalah mubah, kecuali ada dalil yang jelas melarangnya. Beberapa larangan dalam kegiatan pembiayaan dan investasi oleh syariah antara lain adalah transaksi yang mengandung riba, mengandung gharar atau ketidak jelasan, maysir, maksiat, dan kedzaliman. Para ulama sepakat bahwa perdagangan saham dibolehkan secara syariah. Ibnu Qudamah dalam Al-Mughni menyebutkan bahwa jika salah seorang dari dua orang berserikat membeli porsi mitra serikatnya, hukumnya boleh karena ia membeli milik pihak lain (Umam, 2013).

Investasi di pasar modal dewasa ini sangat dilirik oleh para investor. Sebelum melakukan investasi di pasar modal, para investor mencari pertimbangan mengenai situasi pergerakan harga saham di pasar modal saat itu, yang biasa disebut dengan Indeks Harga Saham. Investasi yang dilakukan masyarakat ini salah satunya berada 
pada perusahaan yang memenuhi kriteria syariah. Di Bursa Efek Indonesia (BEI) terdapat beberapa jenis indeks. Diantara indeks tersebut yang beroperasi berdasarkan prinsip syariah adalah Jakarta Islamic Index (JII). JII merupakan subset dari Indeks Harga Saham Gabungan (IHSG) yang diluncurkan pada tanggal 3 Juli 2000 dan menggunakan tahun 1 Januari 1995 sebagai base date (dengan nilai 100). JII melakukan penyaringan terhadap saham yang listing. Rujukan dalam penyaringannya adalah fatwa syariah yang dikeluarkan oleh Dewan Syariah Nasional (Astuti, dkk).

Menurut Tan (2013) Jakarta Islamic Index dimaksudkan untuk digunakan sebagai tolak ukur untuk mengukur kinerja suatu investasi pada saham dengan basis syariah. Melalui indeks diharapkan dapat meningkatkan kepercayaan investor untuk mengembangkan investasi dalam ekuiti secara syariah. Pergerakan indeks dipengaruhi oleh dua faktor yaitu faktor dari dalam negeri (internal) dan faktor dari luar negeri (eksternal).

Faktor yang berasal dari dalam negeri (internal) bisa datang dari fluktuasi nilai tukar mata uang di suatu negara terhadap negara lain, tingkat inflasi dan suku bunga, pertumbuhan ekonomi, kondisi sosial, politik dan keamanan suatu negara, dan lain sebagainya. Sedangkan faktor yang berasal dari luar negeri (eksternal) adalah dari bursa saham yang tergolong dari negara-negara maju seperti Amerika, Jepang, dan Inggris.

Menurut tandelilin (2001) faktor ekonomi makro yang berpengaruh terhadap investasi di suatu negara adalah tingkat pertumbuhan produk domestik bruto, laju pertumbuhan inflasi, tingkat suku bunga, dan nilai tukar mata uang. Banyak teori dan penelitian terdahulu yang mengungkapkan bahwa pergerakan JII dipengaruhi oleh beberapa faktor makro ekonomi.

Beberapa hasil penelitian terdahulu tentang pengaruh nilai tukar, pertumbuhan ekonomi, dan inflasi terhadap Jakarta Islamic Index antara lain penelitian Fitriyanti dan Herlambang (2016), penelitian Kristanti dan Lathifah (2013), penelitian Untono (2015), penelitian Beik dan Fatmawati (2014), penelitian Mulyani (2012), penelitian Rachmawati dan Laila (2015). Penelitian Fitriyanti dan Herlambang (2016) membuktikan bahwa berdasarkan uji $t$, nilai tukar rupiah berpengaruh signifikan terhadap Jakarta Islamic Index. Penelitian tersebut sejalan dengan penelitian Farida Titik Kristanti dan Nur Taufiqoh Lathifah tahun 2013 yang membuktikan bahwa nilai tukar berpengaruh signifikan terhadap Jakarta Islamic Index. Berbeda dengan penelitian Beik dan Fatmawati tahun 2014 yang membuktikan bahwa nilai tukar tidak berpengaruh signifikan terhadap Jakarta Islamic Index.

Penelitian Mulyani (2012) membuktikan bahwa berdasarkan uji t, pertumbuhan ekonomi berpengaruh positif signifikan terhadap Jakarta Islamic Index. Berbeda dengan penelitian Untono (2015) yang membuktikan bahwa pertumbuhan ekonomi tidak berpengaruh positif signifikan terhadap Indeks Harga Saham Gabungan.

Penelitian Kristanti dan Lathifah (2013) membuktikan bahwa inflasi berpengaruh secara signifikan terhadap Jakarta Islamic Index. Berbeda dengan penelitian penelitian Rachmawati dan Laila (2015) yang membuktikan bahwa inflasi tidak berpengaruh secara signifikan terhadap Indeks Harga Saham Gabungan. Dari ketidakkonsistenan hasil penelitian terdahulu yang dilakukan oleh para peneliti, maka penulis tertarik untuk meneliti faktor-faktor yang mempengaruhi Jakarta Islamic Index. 


\section{TINJAUAN LITERATUR}

\section{Nilai Tukar}

Nilai Tukar merupakan catatan harga pasar mata uang asing dalam harga mata uang domestik atau sebaliknya. Faktor-faktor yang mempengaruhi nilai tukar mata uang dolar terhadap rupiah adalah adanya permintaan dan penawaran. Jika nilai tukar mata uang dolar terhadap rupiah naik maka permintaan nilai tukar dolar terhadap rupiah menurun sehingga penawaran nilai tukar dolar terhadap rupiah naik. Kenaikan penawaran nilai tukar dolar terhadap rupiah akan meningkatkan suatu harga. Hal tersebut juga berlaku untuk harga suatu saham. Kenaikan nilai tukar mata uang dolar terhadap rupiah memiliki dampak positif dan negatif terhadap emiten. Artinya harga saham emiten yang terkena dampak positif akan mengalami peningkatan harga di bursa efek sedangkan harga saham emiten yang terkena dampak negatif akan mengalami penurunan harga di bursa efek (Samsul, 2016).

\section{Pertumbuhan Ekonomi}

Pertumbuhan ekonomi adalah proses kenaikan kapasitas produksi suatu perekonomian yang diwujudkan dalam bentuk kenaikan pendapatan nasional. Indikator yang biasa digunakan untuk mengukur pertumbuhan ekonomi adalah data produk domestik bruto (PDB) yang mengukur pendapatan total setiap individu dalam perekonomian (Hasyim, 2016). Pertumbuhan PDB yang cepat merupakan indikasi terjadinya pertumbuhan ekonomi. Jika pertumbuhan ekonomi membaik, maka daya beli masyarakat akan meningkat, dan ini bisa dijadikan perusahaan-perusahaan untuk meningkatkan penjualannya. Dengan meningkatnya penjualan perusahaan, maka kesempatan perusahaan memperoleh keuntungan juga akan semakin meningkat (Tandelilin, 2009). Artinya investor akan tertarik untuk berinvestasi di perusahaan yang bersangkutan sehingga permintaan saham meningkat diikuti oleh kenaikan harga saham.

\section{Inflasi}

Menurut Rahardja dan Manulung (2005), inflasi merupakan gejala kenaikan harga barang-barang yang bersifat umum dan berlangsung secara terus-menerus. Inflasi terjadi karena kecenderungan peningkatan harga produk-produk secara keseluruhan. Tingkat inflasi yang tinggi dikaitkan dengan kondisi ekonomi yang terlalu panas. Artinya, kondisi ekonomi mengalami permintaan atas produk yang melebihi kapasitas penawaran produk sehingga mengakibatkan harga mengalami kenaikan. Inflasi yang terlalu tinggi akan menyebabkan menurunnya daya beli uang dan mengurangi pendapatan riil yang diperoleh investor dari investasinya, sehingga akan menjatuhkan harga saham di pasar (Tandelilin, 2009).

\section{Jakarta Islamic Index}

Jakarta Islamic Index terdiri atas 30 jenis saham yang dipilih dari saham- saham yang sesuai dengan syariah Islam. Jakarta Islamic Index dimaksudkan untuk digunakan sebagai tolak ukur untuk mengukur kinerja suatu investasi pada saham berbasis syariah. 
Melalui indeks diharapkan dapat meningkatkan kepercayaan investor untuk mengembangkan investasi dalam ekuiti secara syariah (Tan, 2009).

Perubahan harga saham individu di pasar terjadi karena faktor permintaan dan penawaran. Terdapat berbagai variabel yang mempengaruhi permintaan dan penawaran, baik yang berupa rasional dan irrasional. Pengaruh yang sifatnya rasional mencakup kinerja perusahaan, tingkat bunga, tingkat inflasi, tingkat pertumbuhan, kurs valuta asing, atau indeks harga saham dari negara lain. Pengaruh yang irrasional mencakup rumor di pasar, mengikuti mimpi, bisikan teman, atau permainan harga. Pada umumnya, kenaikan atau penurunan harga bisa terjadi secara bersama-sama. Jika kenaikan berlangsung terus menerus selama beberapa hari maka hal itu akan diikuti arus balik. Harga terus naik, maka akan diikuti dengan penurunan harga pada periode berikutnya (Samsul, 2015).

\section{Kerangka Berfikir}

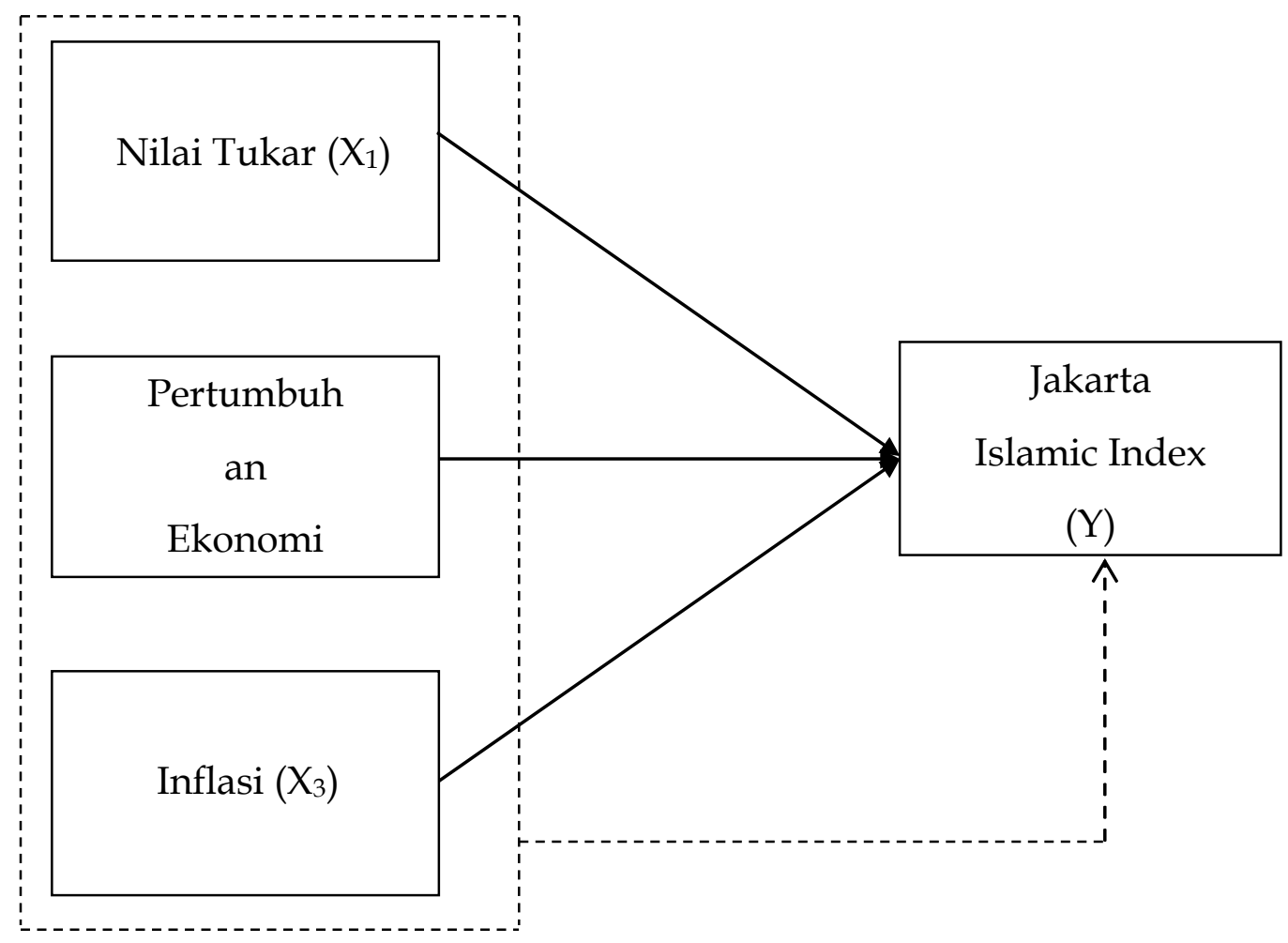

Keterangan:

$$
\begin{aligned}
& =\text { Uji Parsial } \\
& =\text { Uji Simultan }
\end{aligned}
$$

\section{Hipotesis}

\section{$H_{1}$ : Nilai tukar berpengaruh secara signifikan terhadap Jakarta Islamic Index}

Nilai tukar uang merepresentasikan tingkat harga pertukaran satu mata uang ke mata uang lainnya yang digunakan dalam berbagai transaksi seperti transaksi perdagangan internasional, turisme, dan investasi internasional. Faktor-faktor yang mempengaruhi nilai tukar mata uang rupiah terhadap dolar adalah adanya permintaan dan penawaran. Jika nilai tukar mata uang dolar terhadap rupiah naik maka permintaan 
nilai tukar dolar terhadap rupiah menurun sehingga penawaran nilai tukar dolar terhadap rupiah naik.

Kenaikan penawaran nilai tukar dolar terhadap rupiah akan meningkatkan suatu harga. Hal tersebut juga berlaku untuk harga suatu saham. Kenaikan nilai tukar mata uang dolar terhadap rupiah memiliki dampak positif dan negatif terhadap emiten. Artinya harga saham emiten yang terkena dampak positif akan mengalami peningkatan harga di bursa efek sedangkan harga saham emiten yang terkena dampak negatif akan mengalami penurunan harga di bursa efek.

Menurut Rachmawati dan Laila (2015), nilai tukar merupakan nilai dari nilai tukar mata uang dengan mata uang negara lain. Kenaikan nilai tukar mata uang akan membawa dampak yang berbeda pada setiap perusahaan. Bagi perusahaan yang aktivitas utamanya ekspor maka akan mendapat dampak positif dari kenaikan nilai tukar, sedangkan pada perusahaan yang mendapat dampak negatif akan berpengaruh pada penurunan harga saham. Hasil penelitiannya menemukan bahwa nilai tukar berpengaruh negatif secara signifikan terhadap Indeks Saham Syariah Indonesia.

\section{$\mathrm{H}_{2}$ : Pertumbuhan ekonomi berpengaruh secara signifikan terhadap Jakarta Islamic Index}

Pertumbuhan ekonomi didefinisikan sebagai perkembangan kegiatan dalam perekonomian yang menyebabkan barang dan jasa yang diproduksi dalam masyarakat bertambah. Ini berarti kemampuan suatu negara dari periode ke periode untuk menghasilkan barang dan jasa juga akan meningkat. Ukuran produksi barang dan jasa total suatu negara disebut PDB. Pertumbuhan PDB yang cepat merupakan indikasi terjadinya pertumbuhan ekonomi.

Jika pertumbuhan ekonomi membaik, maka daya beli masyarakat akan meningkat, dan ini bisa dijadikan perusahaan-perusahaan untuk meningkatkan penjualannya. Dengan meningkatnya penjualan perusahaan, maka kesempatan perusahaan memperoleh keuntungan juga akan semakin meningkat. Artinya investor akan tertarik untuk berinvestasi di perusahaan yang bersangkutan sehingga permintaan saham meningkat diikuti oleh kenaikan harga saham. Hasil penelitian Mulyani (2012) menemukan bahwa pertumbuhan ekonomi berpengaruh positif dan signifikan terhadap Jakarta Islamic Index.

\section{$\mathrm{H}_{3}$ : Inflasi berpengaruh secara signifikan terhadap Jakarta Islamic Index}

Inflasi terjadi karena kecenderungan peningkatan harga produk-produk secara keseluruhan. Tingkat inflasi yang tinggi dikaitkan dengan kondisi ekonomi yang terlalu panas. Artinya, kondisi ekonomi mengalami permintaan atas produk yang melebihi kapasitas penawaran produk sehingga mengakibatkan harga mengalami kenaikan. Inflasi yang terlalu tinggi akan menyebabkan menurunnya daya beli uang dan mengurangi pendapatan riil yang diperoleh investor dari investasinya, sehingga akan menjatuhkan harga saham di pasar.

Inflasi yang berlebihan dapat merugikan perekonomian yaitu banyak perusahaan yang mengalami kebangkrutan. Inflasi yang tinggi akan menjatuhkan harga saham di pasar, sementara inflasi yang rendah akan memperlambat pergerakan harga saham. Hasil penelitian Kristanti dan Lathifah (2013) menemukan bahwa inflasi berpengaruh negatif dan signifikan terhadap Jakarta Islamic Index. 
$\mathrm{H}_{4}$ : Nilai tukar, pertumbuhan ekonomi, dan inflasi berpengaruh secara signifikan terhadap Jakarta Islamic Index

Faktor makro merupakan faktor yang mempunyai pengaruh terhadap kenaikan atau penurunan kinerja perusahaan. Faktor makro ekonomi yang secara langsung dapat mempengaruhi kinerja saham maupun kinerja perusahaan adalah tingkat bunga umum domestik, tingkat inflasi, perpajakan, kurs valuta asing, dan sebagainya. Menurut Tandellin, faktor ekonomi makro yang berpengaruh terhadap investasi di suatu negara adalah tingkat pertumbuhan produk domestik bruto, laju pertumbuhan inflasi, tingkat suku bunga, dan nilai tukar mata uang.

\section{METODE}

Jenis penelitian yang digunakan adalah penelitian asosiatif yang termasuk penelitian kausal. Menurut Suliyanto, penelitian kausal adalah penelitian yang bertujuan untuk mengetahui pengaruh antar variabel. Jadi penelitian ini ingin mengetahui besarnya pengaruh nilai tukar, pertumbuhan ekonomi, dan inflasi terhadap Jakarta Islamic Index di Bursa Efek Indonesia periode 2017-2018. Penelitian ini menggunakan pendekatan penelitian kuantitatif. Sampel penelitian ini adalah data nilai tukar, pertumbuhan ekonomi, inflasi dan Jakarta Islamic Index bulanan selama tahun 20172018.

\section{Variabel Penelitian}

Variabel bebas

a. Nilai tukar adalah catatan harga pasar mata uang asing dalam harga mata uang domestik atau sebaliknya. Variabel nilai tukar yang dikeluarkan oleh Bank Indonesia secara bulanan tahun 2017-2018.

b. Pertumbuhan ekonomi adalah proses perubahan kondisi perekonomian suatu negara secara berkesinambungan menuju keadaan yang lebih baik selama periode tertentu. Variabel ini diukur dengan mencatat data PDB yang diterbitkan oleh BPS secara bulanan tahun 2017-2018.

c. Inflasi adalah suatu kecenderungan terjadinya kenaikan harga-harga umum secara terus-menerus. Variabel ini diukur dengan mencatat data tingkat inflasi yang diterbitkan oleh BPS secara bulanan tahun 2017-2018.

Variabel terikat

Variabel terikat dalam penelitian ini adalah Jakarta Islamic Index. JII merupakan indeks saham yang menghitung index harga rata-rata saham untuk jenis kegiatan usaha yang memenuhi kriteria syariah. Variabel ini diukur dengan mencatat harga-harga saham yang masuk dalam Jakarta Islamic Index secara bulanan periode 2017-2018.

\section{Metode Analisis Data}

Penelitian ini mengunakan analisis regresi linier berganda untuk menguji pengaruh Nilai Tukar Rupiah, Inflasi dan Pertumbuhan Ekonomi terhadap Jakarta Islamic Index. Sebelum melakukan uji regresi dilakukan uji asumsi klasik terlebih dahulu untuk 
mendekteksi ada atau tidaknya penimpangan asumsi klasik atau persamaan regresi berganda yang digunakan.

\section{HASIL DAN PEMBAHASAN}

\section{Analisis Uji Asumsi Klasik}

\section{Uji Normalitas}

Uji normalitas bertujuan untuk menguji apakah dalam model regresi, variabel pengganggu atau residual memiliki distribusi normal. Cara mendeteksi apakah residual berdistribusi normal atau tidak yaitu dengan analisis grafik dan uji statistic (Sugiyono, 2005). Dengan melihat uji normalitas dari hasil test of normality diketahui nilai statistik 0.138 atau nilai sig 0.20 atau 20\%. Dimana nilai tersebut lebih besar dari nilai $\alpha 5 \%$, sehingga dapat disimpulkan bahwa residual menyebar normal.

\section{Uji Heteroskedastisitas}

Pengujian heteroskedastisitas dilakukan dengan membuat scatterplot (alur sebaran) antara residual dan nilai prediksi dari variabel terikat yang telah distandarisasi (Ghozali, 2011). Berdasarkan hasil pengujian seperti tampak pada output spss di atas dapat dilihat bahwa titik-titik data tidak membentuk pola tertentu dan data menyebar di atas dan di bawah angka 0 pada sumbu Y. Maka dari itu dapat disimpulkan tidak terjadi gangguan asumsi heteroskedastisitas yang artinya model regresi ini sudah baik.

\section{Uji Autokorelasi}

Uji autokorelasi bertujuan untuk melihat apakah dalam model regresi linear ada korelasi antara kesalahan pengganggu pada periode $t$ dengan kesalahan pengganggu pada periode t-1 (sebelumnya). Untuk mengetahui adanya autokorelasi dalam suatu model regresi dilakukan melalui pengujian dengan uji Run test (Ghozali, 2011). Berdasarkan output SPSS di atas, diketahui nilai Asymp.Sig. (2-tailed) sebesar 0.060. Nilai tersebut lebih besar dari nilai signifikan 0.05, maka dapat disimpulkan bahwa tidak terdapat masalah autokorelasi.

\section{Uji Multikolinearitas}

Uji multikolinearitas bertujuan untuk menguji apakah model regresi ditemukan adanya korelasi antar variabel bebas (independent variabel). Cara melihat ada atau tidaknya multikolinearitas dilihat dari nilai tolerance dan nilai variance inflation factor (VIF). Berdasarkan tabel output Coefficients diketahui nilai tolerance untuk variabel nilai tukar adalah 0.452 , variabel pertumbuhan ekonomi adalah 0.525 , variabel inflasi adalah 0.414 lebih besar dari 0.10. Sementara nilai VIF untuk variabel nilai tukar adalah 2.210, variabel pertumbuhan ekonomi adalah 1.904, variabel inflasi adalah 2.418 kurang dari 10.00. Hasil perhitungan nilai VIF dari ketiga variabel tidak ada yang lebih dari 10.00, maka mengacu pada dasar pengambilan keputusan dalam uji multikolinearitas dapat disimpulkan bahwa tidak terjadi gejala multikolinearitas dalam model regresi. 


\section{Analisis Regresi Linier Berganda}

Regresi linier berganda adalah alat yang dapat digunakan untuk mengetahui pengaruh satu variabel atau lebih variabel bebas (independen) terhadap satu variabel terikat (dependen). Dalam penelitian ini terdapat 3 variabel independen dan 1 variabel dependen. Persamaan regresi untuk tiga prediktor adalah:

$Y=a+b_{1} X_{1}+b_{2} X_{2}+b_{3} X_{3}$

Keterangan :

$\begin{array}{ll}\mathrm{a} & =\text { Konstanta } \\ \mathrm{b}_{1}, \mathrm{~b}_{2}, \mathrm{~b}_{3} & =\text { Koefisien Regresi Variabel } \\ \mathrm{X}_{1} & =\text { Nilai Tukar Rupiah } \\ \mathrm{X}_{2} & =\text { Pertumbuhan Ekonomi } \\ \mathrm{X}_{3} & =\text { Inflasi } \\ \mathrm{Y} & =\text { Jakarta Islamic Index }\end{array}$

Tabel 1

Rekapitulasi Analisis Regresi Berganda Variabel Nilai Tukar, Pertumbuhan Ekonomi, dan Inflasi Terhadap Jakarta Islamic Index

\begin{tabular}{|l|l|l|l|l|}
\hline Variabel & $\begin{array}{l}\text { Unstandardized } \\
\text { Coefficients (B) }\end{array}$ & thitung & Sig & Keterangan \\
\hline Konstanta & 253.684 & 3.548 & .002 & \\
\hline Nilai Tukar (X1) & -.008 & -4.375 & .000 & Signifikan \\
\hline $\begin{array}{l}\text { Pertumbuhan } \\
\text { Ekonomi (X2) }\end{array}$ & -5.453 & -.426 & .675 & $\begin{array}{l}\text { Tidak } \\
\text { Signifikan }\end{array}$ \\
\hline Inflasi (X3) & -1.488 & -.448 & .659 & $\begin{array}{l}\text { Tidak } \\
\text { Signifikan }\end{array}$ \\
\hline $\begin{array}{l}\text { R = } \quad .819 \\
\text { Adj. Rsquare }=.622\end{array}$ & & & & \\
\hline
\end{tabular}

$\mathrm{Y}=253.684-0.008 \mathrm{X}_{1}-5.453 \mathrm{X}_{2}-1.488 \mathrm{X}_{3}+\mathrm{e}$

Berdasarkan nilai koefisien regresi dari masing-masing variabel yang mempengaruhi Jakarta Islamic Index $(\mathrm{Y})$ dengan menggunakan tingkat signifikansi $\alpha=0.05$ dapat diinterpretasikan sebagai berikut:

(a) Nilai konstanta dari hasil penelitian menunjukkan nilai yang positif yaitu 253.684, artinya bahwa jika tidak ada pengaruh dari variabel bebas seperti nilai tukar rupiah, pertumbuhan ekonomi, dan inflasi, maka variabel terikat Jakarta Islamic Index memiliki nilai sebesar 253.684.

(b) Variabel nilai tukar rupiah sebesar -0.008 menunjukkan arah hubungan negatif atau berlawanan arah antara nilai tukar rupiah dengan perubahan Jakarta Islamic Index. Artinya bahwa jika variabel nilai tukar rupiah naik 1 satuan maka Jakarta Islamic Index akan turun sebesar 0.008 . 
(c) Variabel pertumbuhan ekonomi sebesar -5.453 menunjukkan arah hubungan negatif atau berlawanan arah antara pertumbuhan ekonomi dengan perubahan Jakarta Islamic Index. Artinya bahwa jika variabel pertumbuhan ekonomi naik 1 satuan maka Jakarta Islamic Index akan turun sebesar 5.453.

(d) Variabel inflasi sebesar -1.488 menunjukkan arah hubungan negatif atau berlawanan arah antara inflasi dengan perubahan Jakarta Islamic Index. Artinya bahwa jika variabel inflasi naik 1 satuan maka Jakarta Islamic Index akan turun sebesar 1.488.

(e) Koefisien e atau eror menunjukkan bahwa terdapat variabel lain yang mempengaruhi indeks harga saham gabungan yang tidak dimasukkan dalam penelitian ini.

\section{Pengujian Hipotesis}

Tabel 2

Hasil Uji Hipotesis

\begin{tabular}{|c|c|c|c|c|}
\hline No & Hipotesis & Hasil & Simpulan & Artinya \\
\hline 1. & $\begin{array}{l}\text { Nilai tukar } \text { berpengaruh } \\
\text { secara } \\
\text { terhadap Jakarta Islamic } \\
\text { Index }\end{array}$ & & $\mathrm{H}_{1}$ diterima & $\begin{array}{lr}\text { Nilai } & \text { tukar } \\
\text { berpengaruh secara } \\
\text { signifikan terhadap } \\
\text { Jakarta Islamic } \\
\text { Index }\end{array}$ \\
\hline 2. & $\begin{array}{lr}\text { Pertumbuhan } & \text { ekonomi } \\
\text { berpengaruh } & \text { secara } \\
\text { signifikan } & \text { terhadap } \\
\text { Jakarta Islamic Index }\end{array}$ & $0.675>0.05$ & $\mathrm{H}_{2}$ ditolak & $\begin{array}{l}\text { Pertumbuhan } \\
\text { ekonomi tidak } \\
\text { berpengaruh secara } \\
\text { signifikan terhadap } \\
\text { Jakarta Islamic } \\
\text { Index }\end{array}$ \\
\hline 3. & $\begin{array}{lr}\text { Inflasi } & \text { berpengaruh } \\
\text { secara } & \text { signifikan } \\
\text { terhadap } & \text { Jakarta } \\
\text { Index } & \end{array}$ & & $\mathrm{H}_{3}$ ditolak & $\begin{array}{l}\text { Inflasi ridak } \\
\text { berpengaruh secara } \\
\text { signifikan terhadap } \\
\text { Jakarta Islamic } \\
\text { Index }\end{array}$ \\
\hline
\end{tabular}




\begin{tabular}{|c|c|c|c|}
\hline 4. & $\begin{array}{lr}\text { Nilai } & \text { tukar, } \\
\text { pertumbuhan } & \text { ekonomi, } \\
\text { dan inflasi } & \text { berpengaruh } \\
\text { secara } & \text { signifikan } \\
\text { terhadap Jakarta } & \text { Islamic } \\
\text { Index } & \end{array}$ & $\mathrm{H}_{4}$ diterima & $\begin{array}{l}\text { Nilai tukar, } \\
\text { pertumbuhan } \\
\text { ekonomi, dan inflasi } \\
\text { berpengaruh secara } \\
\text { signifikan terhadap } \\
\text { Jakarta Islamic } \\
\text { Index }\end{array}$ \\
\hline
\end{tabular}

\section{Pembahasan}

\section{Nilai tukar berpengaruh sccara signifikan terhadap Jakarta Islamic Index}

Hasil penelitian menunjukkan bahwa nilai tukar rupiah berpengaruh secara signifikan terhadap Jakarta Islamic Index. Hal ini didukung oleh teori neo klasik yang menyatakan bahwa kenaikan penawaran uang (permintaan rupiah lebih kuat) yang signifikan maka otomatis akan terjadi kenaikan harga yang signifikan pula dan akan berdampak positif dan negatif terhadap emiten. Hal ini sejalan dengan penelitian yang dilakukan oleh Fitriyanti dan Herlambang (2016) dan penelitian Mulyani (2012) yang menunjukkan nilai tukar rupiah berpengaruh secara signifikan terhadap Jakarta Islamic Index. Sedangkan hal ini tidak sejalan dengan penelitian yang dilakukan Beik dan Sri Fatmawati (2014) yang menunjukkan nilai tukar rupiah tidak berpengaruh signifikan terhadap Jakarta Islamic Index.

\section{Pertumbuhan ekonomi tidak berpengaruh secara signifikan terhadap Jakarta Islamic Index}

Hasil penelitian menunjukkan bahwa pertumbuhan ekonomi tidak berpengaruh secara signifikan terhadap Jakarta Islamic Index. Hal ini tidak sejalan dengan Istijanto yang menyatakan bahwa ekonomi yang tumbuh menunjukkan investasi saham yang menarik sehingga harga saham naik. Tetapi sejalan dengan penelitian Wahyu dan Agung (2018) yang menyatakan bahwa ketika pertumbuhan ekonomi naik maka indeks harga saham gabungan turun, hal tersebut karena struktur kegiatan ekonomi di Indonesia yang didominasi oleh kegiatan informal dan pertanian juga menjadi penyebab keterbatasan kemampuan pencatatan sehingga ketika PDB meningkat belum tentu pendapatan perkapita setiap individu meningkat sehingga pola investasi dipasar modal tidak berpengaruh oleh adanya peningkatan PDB. Hal ini sejalan dengan penelitian yang dilakukan oleh Wahyu dan Agung (2018) yang menunjukkan pertumbuhan ekonomi tidak berpengaruh signifikan terhadap indeks harga saham gabungan. Sedangkan hal ini tidak sejalan dengan penelitian Mulyani (2012) yang menunjukkan pertumbuhan ekonomi berpengaruh signifikan terhadap Jakarta Islamic Index. 


\section{Inflasi tidak berpengaruh secara signifikan terhadap Jakarta Islamic Index}

Hasil penelitian menunjukkan bahwa inflasi tidak berpengaruh secara signifikan terhadap Jakarta Islamic Index. Hal ini tidak sejalan dengan Eduardus Tandellin yang menyatakan inflasi yang tinggi akan menjatuhkan harga saham di pasar. Tetapi sejalan dengan penelitian Martien Rachmawati dan Nisful Laila yang menyatakan bahwa ketika inflasi naik maka ISSI akan turun, hal ini terjadi karena investor tidak menggunakan tingkat inflasi sebagai tolak ukur untuk membuat keputusan dalam melakukan investasi. Hal ini sejalan dengan penelitian yang dilakukan oleh Rachmawati dan Laila (2015) dan Astuti, Apriatni, dan Susanta (2013) yang menunjukkan inflasi tidak berpengaruh signifikan terhadap indeks harga saham gabungan. Sedangkan hal ini tidak sejalan dengan penelitian yang dilakukan Kristanti dan Lathifah (2013) yang menunjukkan inflasi berpengaruh signifikan terhadap Jakarta Islamic Index.

\section{Nilai tukar, pertumbuhan ekonomi, dan inflasi berpengaruh secara signifikan terhadap Jakarta Islamic Index}

Tandellin (2009) merangkum beberapa faktor ekonomi makro yang berpengaruh terhadap investasi di suatu negara adalah tingkat pertumbuhan produk domestik bruto, laju inflasi, tingkat suku bunga, dan nilai tukar mata uang. Berdasarkan hasil perhitungan program SPSS versi 16 dapat diketahui bahwa nilai $F_{\text {hitung }}$ sebesar 13.605 dan nilai probabiliti sebesar 0.000. Secara simultan nilai $F_{\text {hitung }}>F_{\text {tabel }}(13.605>3.10)$, maka terdapat pengaruh yang signifikan antara nilai tukar rupiah, pertumbuhan ekonomi, dan inflasi terhadap Jakarta Islamic Index.

\section{SIMPULAN}

Variabel nilai tukar rupiah berpengaruh secara signifikan terhadap Jakarta Islamic Index. Hal ini didukung oleh teori neo klasik yang menyatakan bahwa kenaikan penawaran uang (permintaan rupiah lebih kuat) yang signifikan maka otomatis akan terjadi kenaikan harga yang signifikan pula dan akan berdampak positif terhadap emiten. Sedangkan variabel pertumbuhan ekonomi dan inflasi tidak berpengaruh secara signifikan terhadap Jakarta Islamic Index.

Pertumbuhan ekonomi tidak berpengaruh karena struktur kegiatan ekonomi di Indonesia yang didominasi oleh kegiatan informal dan pertanian juga menjadi penyebab keterbatasan kemampuan pencatatan sehingga ketika PDB meningkat belum tentu pendapatan perkapita setiap individu meningkat sehingga pola investasi dipasar modal tidak berpengaruh oleh adanya peningkatan PDB. Sedangkan inflasi tidak berpengaruh karena investor tidak menggunakan tingkat inflasi sebagai tolak ukur untuk membuat keputusan dalam melakukan investasi.

Saran untuk penelitian selanjutnya dapat mempertimbangkan variabel ekonomi makro yang lain. Sedangkan bagi investor perlu memperhatikan faktor ekonomi makro dalam berinvestasi. Salah satu variabel ekonomi makro yang berpengaruh signifikan terhadap Jakarta Islamic Index yaitu nilai tukar rupiah. Maka dari itu, investor perlu memperhatikan nilai tukar rupiah ketika akan melakukan investasi di pasar modal. 


\section{DAFTAR PUSTAKA}

Astuti, Ria. (2013) Analisis Pengaruh Tingkat Suku Bunga (SBI), Nilai Tukar (Kurs) Rupiah, Inflasi, dan Indeks Bursa Internasional Terhadap IHSG. Diponegoro Journal of Social and Politic of Science Vol. 12, No.1.

Beik, Irfan Syauqi dan Sri Wulan Fatmawati. (2014). Pengaruh Indeks Harga Saham Syariah Internasional dan Variabel Makro Ekonomi Terhadap Jakarta Islamic Index. Jurnal Ilmu Ekonomi Syariah Vol. 6, No. 2.

Darmadji, Tjiptono, dan Hendy M. Fakhruddin. Pasar Modal di Indonesia. Jakarta: Salemba Empat, 2001.

Fitriyanti, Ika dan Leo Herlambang. (2016). Analisis Pengaruh Variabel Makroekonomi dan Harga Komoditas Terhadap Jakarta Islamic Index. Jurnal Ekonomi Syariah Teori dan Terapan Vol. 3, No. 9.

Ghozali, Imam. Aplikasi Analisis Multivariate dengan Program IBM SPSS 19. Semarang: Badan Penerbit Universitas Diponegoro, 2011.

Hadi, Nor. Pasar Modal Edisi 2. Yogyakarta: Graha Ilmu, 2015.

Hasyim, Ali Ibrahim. Ekonomi Makro Edisi Pertama. Jakarta: Prenadamedia Group, 2016.

Jamli, Ahmad. Teori Ekonomi Makro Edisi Pertama. Yogyakarta: BPFE, 2001.

Karim, Adiwarman Azwar. Ekonomi Islam: Suatu Kajian Ekonomi Makro. Jakarta: IIIT Indonesia, 2002.

Kristanti, Farida Titik dan Nur Taufiqoh Lathifah. (2013). Pengujian Variabel Makro Ekonomi Terhadap Jakarta Islamic Index. Jurnal Keuangan dan Perbankan Vol. 17, No. 1.

Lipsey, Richard G, dkk. Pengantar Makroekonomi. Terjemahan oleh A. Jaka Wasana dan Kirbrandoko. Jakarta: Erlangga, 1992.

Mujayana, Marya. (2013). Pengaruh Makro Ekonomi Terhadap Indeks Harga Saham Gabungan (IHSG). Jurnal SNASTI Vol. 6, No. 2.

Mulyani, Neny. (2012) Analisis Pengaruh Inflasi, Suku Bunga, Nilai Tukar Rupiah, dan Produk Domestik Bruto Terhadap Jakarta Islamic Index. Jurnal Akuntansi Terapan Vol. 7, No. 1.

Oei, Istijanto. Kiat Investasi Valas, Emas, Saham: Panduan, Praktis Membiakkan Uang Lewat Valas, Emas, dan Saham yang Penuh Gejolak. Jakarta: Gramedia, 2009.

Pradja, Juhaya S. Pasar Modal Syariah: Praktik Pasar Modal Syariah. Bandung: Pustaka Setia, 2013.

Pratiwi, Enggar, dan Riko Hendrawan. (2014). Pengaruh Indeks Harga Saham Gabungan, Faktor Ekonomi Makro dan Indeks Dow Jones Industrial Average Terhadap Indeks Harga Saham LQ45 Periode 2008-2012 dalam Keputusan Investasi. Jurnal Manajemen Indonesia Vol. 14, No. 1.

Rachmawati, Martien, dan Nisful Laila. (2015). Faktor Makro ekonomi yang Mempengaruhi Pergerakan Harga Saham Pada Indeks Saham Syariah Indonesia (ISSI) di Bursa Efek Indonesia (BEI). Jurnal JESTT Vol. 11 No. 2

Rahardja, Prathama, dan Mandala Manulung. Teori Ekonomi Makro: Suatu Pengantar. Jakarta: Lembaga Penerbit Fakultas Ekonomi Universitas Indonesia, 2005.

S, Burhanuddin. Pasar Modal Syariah. Yogyakarta: UII Press, 2009.

Samsul, Mohamad. Pasar Modal dan Manajemen Portofolio. Jakarta: Erlangga, 2015. 
Siregar, Syofian. Metode Penelitian Kuantitatif: Dilengkapi dengan Perbandingan Perhitungan Manual \& SPSS. Jakarta: Prenadamedia Group, 2015.

Suliyanto. Metode Riset Bisnis. Yogyakarta: Andi Offset, 2009.

Tan, Inggrid. Bisnis dan Investasi Sistem Syariah. Yogyakarta: Universitas Atma Jaya, 2009. Tandelilin, Eduardus. Analisis Investasi dan Manajemen Portofolio. Yogyakarta: BPFE, 2009.

Triani, Lely Fera. (2013). Faktor-Faktor yang Mempengaruhi Perubahan Indeks Harga Saham di Jakarta Islamic Index Selama Tahun 2011. Jurnal Organisasi dan Manajemen Vol. 9, No. 2.

Umam, Khaerul. Pasar Modal Syariah dan Praktik Pasar Modal Syariah. Bandung: Pustaka Setia, 2013.

Untono, Michael. (2015) Analisis Pengaruh Pertumbuhan Ekonomi, Inflasi, Nilai Tukar, Indek DJIA, dan Harga Minyak Dunia Terhadap Indeks Harga Saham Gabungan. Jurnal Parsimonia Vol. 2, No. 2.

Widoatmodjo, Sawidji. Seri Membuat Uang Bekerja Untuk Anda Cara Sehat Investasi di Pasar Modal Pengantar Menjadi Investor Profesional. Jakarta: Gramedia, 2005.

Wirartha, I Made. Metodologi Penelitian Sosial Ekonomi. Yogyakarta: Andi Offset, 2006 
